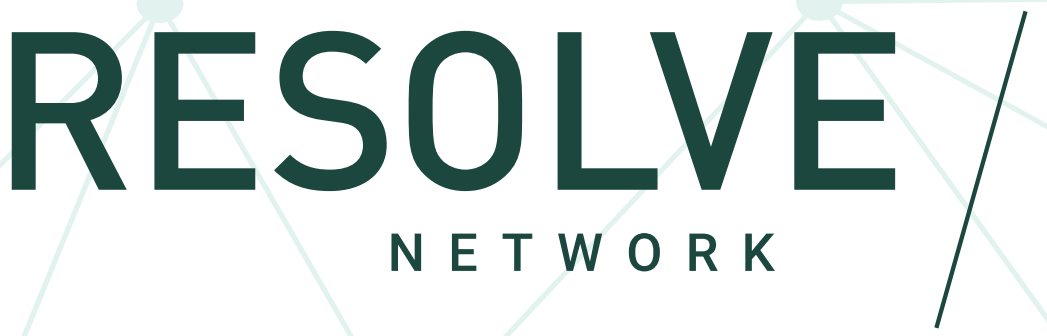

\title{
Community-centered P/CVE Research in Southeast Asia: Opportunities and Challenges
}

Matteo Vergani 


\section{ABSTRACT}

The definition and understanding of community-centered preventing and countering violent extremism (P/CVE) research lacks analytical clarity. This chapter examines this concept with a focus on the Southeast Asian context, reflecting on opportunities, challenges, and pitfalls, to lay the foundation for future theorization and comparative P/CVE research in local contexts. Collaboration with independent and genuine community actors is advantageous for all stakeholders, since deficient trust, tamed and crystallized relationships, and a lack of resources and capacities can result in biased research findings. The chapter advocates for the establishment of research and evaluation frameworks in National Action Plans, with the aim to set out common definitions, measurement tools, and methodologies in consultation with all stakeholders, including community actors. This is a necessary step in producing systematic, cumulative, and comparative research and evaluation findings that hold true across local contexts. Finally, the chapter discusses the ethical implications of conducting community-centered P/CVE research with minority communities--such as the creation of suspicious, ostracized, and alienated communities--as well as with majority communities. It also speaks to the potential for research findings and topics of focus interfering in or being instrumentalized to impact a country's democratic process. Although the Southeast Asian context is used to discuss the opportunities and challenges of the different approaches to community-centered P/CVE research, key findings are likely relevant to other contexts. 


\section{INTRODUCTION}

Holistic and whole-of-society approaches to preventing and countering violent extremism (P/CVE) have been gaining traction globally, including in Southeast Asia. Numerous initiatives have been introduced, with various degrees of success, to bring stakeholders from governmental and non-governmental backgrounds together to learn from each other, cross-pollinate best practices, and improve the quality and effectiveness of P/CVE work in the region. Some of these initiatives have stemmed from high-level efforts, such as the resolutions of the Association of Southeast Asian Nations (ASEAN), which have highlighted in multiple documents over the years the need to build trust and strengthen cooperation between government agencies and civil society organizations in P/CVE work ${ }^{1}$. The Australian government has also contributed to creating momentum for a holistic, regional P/CVE approach in Southeast Asia by sponsoring initiatives working together on P/CVE, such as the Southeast Asian Network of Civil Society Organizations (SEAN-CSO) and the working group on CVE of the Global Counter Terrorism Forum (GCTF), co-convened by Australia and Indonesia.

Research has been a key focus of all these efforts for many purposes: to inform and evaluate P/CVE policy and programming, to identify the root causes and risk factors of radicalization in different contexts, to understand terrorist and extremist threats and trends, and to understand resilience factors, among others. Community actors are key to P/CVE research because they can access social groups that are hard to reach for various reasons (for example, because they lack trust in research and government institutions and perceive to be over-researched and treated as suspicious communities). Moreover, community actors are key to translate research into actionable knowledge that is useful to P/CVE practitioners who work with individuals at risk of radicalization.

Broadly, communities can be part of the research-practice cycle in two ways: they can be both the subject and the object of research. As the subject of research - that is, those undertaking research-communities are understood as a diverse galaxy of formal and informal entities, such as local and international NGOs, community organizations, individual activists, social enterprises, think-tanks, and research centers. They undertake research independently or in partnership with other organizations, such as governments or universities, in various capacities and in different phases of the research. As the object of research, communities are often an ephemeral notion that sometimes incorporates very narrow groups, on a geographical or ethnic basis for example, and can embrace large populations, such as national or even multinational identities (e.g. the Malay identity, which is found across multiple Southeast Asian states).

The definition and understanding of communities as both the subject and object of P/CVE research lacks analytical clarity. This chapter aims to dissect and disentangle the meaning of community-centered

1 Association of Southeast Asian Nations (ASEAN), "Asean Plan Of Action To Prevent And Counter The Rise Of Radicalisation And Violent Extremism (2018 - 2025)," 2018, https://asean.org/storage/2012/05/Adopted-ASEAN-PoA-to-Prevent-and-Counter-PCVE.pdf 
research with a focus on the Southeast Asian context, reflecting on opportunities, but also the challenges and pitfalls of this approach to P/CVE. It draws on research and engagement experience in Indonesia, Malaysia, the Philippines, and Thailand, discussing relevant scholarly and gray-area literature about community-centered CVE efforts in these four national contexts.

\section{DEFINING COMMUNITY-CENTERED P/CVE RESEARCH}

One of the main challenges in conceptualizing the notion of community-centered $P / C V E$ research is the diversity of meanings that are attributed to each of the terms: community, P/CVE, and research.

\section{Mixed definitions: community}

Community is a loose concept that denotes a group of people with some characteristic, whether real or perceived, in common. As per the classic study of nationalism by Anderson, ${ }^{2}$ communities are socially constructed by perception and are strongly influenced by media (including social media) and a number of other structural, group-based, and individual factors such as common grievances, education, and socio-economic conditions. It is useful to talk about communities as a fractal. Like snowflakes or broccoli, the closer we look at a community, the more sub-communities we can identify. Seen from a distance, these differences tend to disappear, and the boundaries of larger communities can be drawn, especially in comparison with other groups.

Let us take for example students of Islam in Indonesia. If we look closely enough, all pesantren (communal boarding schools housing madrasah, or Islamic schools) are different from one another, because of the personal styles of the kyai (the head of the pesantren), the charisma of the teachers, and the socio-demographic composition of student body. Zooming out, we notice that some groups of pesantren are different from others, because they are affiliated with different organizations. Some are associated with the traditionalist Nahdlatul Ulama (NU), others with Muhammadiyah, and others still are independent. Some pesantren only teach religious content (known as Pesantren Salafiyah-'original' pesantren), and others also teach national curriculum subjects, such as the sciences, arts, and humanities. ${ }^{3}$ However, if we zoom out further, we can see that pesantren are different from schools, especially in urban areas. Thus, can santri-that is, the students of a pesantren-be considered a community? In this case, it depends on how and why we use the concept of community in relation to P/CVE research and practice.

Identities are political by nature, and in Southeast Asia many religious and political organizations tend to define the boundaries of their communities of reference around the identities that are most convenient to their agenda. This tendency is not uncommon in P/CVE, and it requires profound local knowledge to

2 Benedict Anderson, Imagined communities: Reflections on the origin and spread of nationalism (London: Verso books, 2006).

3 Greg Barton, Gus Dur: The Authorized Biography of Abdurrahman Wahid (UK: Equinox Publishing, 2002). 
understand how and why biases play out in defining community boundaries. For example, research conducted among pesantren associated only with NU or only with Muhammadiyah would provide a biased vision of the community of santri. These considerations are crucial when designing research in this field.

Furthermore, it is useful to split the notion of community into two conceptually different (but in practice often overlapping) camps. On the one hand, there are community members, a collection of individuals who belong (or are perceived to belong) to a certain group. On the other hand, there is a galaxy of community actors composed of activists, leaders (real or self-proclaimed), organizations, and NGOs, who each claim to somehow represent the interests of community members. The two camps overlap because the former often belongs to the latter-community actors are community members themselves. However, the degree to which they really represent the broader interests of community members and their actual connectedness with the community is mixed. It is important to always consider competition for resources and the political agendas of subgroups within each community. Going back to the metaphor of fractals, the more we zoom in, the easier is to find legitimate community actors, smaller groups are more homogenous and can more easily find local actors to represent their interests. On the other hand, the larger the community, the more difficult is to find legitimate community actors that are accepted by large and diverse communities.

\section{Mixed definitions: P/CVE}

$\mathrm{P} / \mathrm{CVE}$ is a broad field that incorporates all non-coercive, preventative forms of counterterrorism. Scholars and practitioners often use the label P/CVE to refer to a diversity of activities, which can be grouped into primary, secondary, and tertiary levels, as in the public health model. Primary interventions are implemented before the occurrence of terrorism and violent extremism, aiming to address the root causes and risk factors of radicalization. For example, primary interventions include education and strategic communication programs that target groups within the general population (for example school students) and aim to prevent them from adopting violent extremist ideologies. Secondary interventions are implemented after an individual or a group has started the radicalization process but before they engage in serious ideologically motivated crime. They include one-to-one mentoring programs targeting individuals who show indications or warning signs of radicalization to violent extremism and aim to prevent them from engaging in acts of violence.

Tertiary interventions are implemented after the crime is committed, usually after terrorists are imprisoned or released from prison after serving their sentence. For example, they include programs to rehabilitate and reintegrate former terrorists back into the community. Research that aims to underpin and support activities in the primary, secondary, and tertiary levels needs to work with different methodologies because of the different size and characteristics of the target population. For instance, research related to primary P/CVE activities can usually use large samples and quantitative techniques, while research related to secondary and tertiary $P / C V E$ interventions can usually rely on small samples and qualitative design. Therefore all requires different approaches to research, monitoring, and evaluation. 
Primary P/CVE interventions are the most common globally, and South East Asia is no exception. In 2017, a study surveyed 60 civil society organizations and researchers working on P/CVE from Indonesia, Malaysia, the Philippines, and Thailand, ${ }^{4}$ finding that 54 of them worked exclusively on primary interventions, compared to only one on secondary and three on tertiary.

\section{Mixed definitions: research}

Finally, it is important to underline that the notion of research is also used inconsistently to refer to a range of different activities. Scholars know well that different ontologies and epistemologies can lead to different research activities. There is a continuum of positions between those who believe that reality can be studied using scientific methods and those, at the other end of the spectrum, who believe that meanings and realities only exist as mental constructions within subjects. ${ }^{5}$ These differences shape not only academic research but also the research approaches of community actors, including activists, NGOs, civil society organizations, and others. In Southeast Asia, the majority of P/CVE community actors that I have encountered in my activities as part of SEAN-CSO position themselves on the latter end of the spectrum and adopt a relativist and subjectivist approach and tend to reject the use of the scientific method. This has important implications for the type and range of research conducted in P/CVE by communities, because it narrows the toolkit of methods used by community researchers in this region. This is not unique to Southeast Asia, as it reflects the methods used in the field of radicalization research generally. ${ }^{6}$

The different combinations of the possible meanings of these three terms-communities, P/CVE, and research-often end up including vastly different activities and approaches under the same umbrella of community-centered P/CVE research. More narrow definitions of communities are usually associated with research relevant to localized approaches. In the primary P/CVE space, such research might inform or evaluate programs in narrowly defined geographical communities (for example development programs), or in the tertiary P/CVE space, programs for convicted terrorists. Broader definitions of communities are associated with research relevant to mainstream approaches. In the secondary P/CVE space, this research might underpin risk assessment indicators aiming at detecting early signs of radicalization

4 Greg Barton, Matteo Vergani, Dan Goodhardt, Husnul Atiyah, “Gap Analysis and Capacity Assessment of Society Organisations Working against Violent Extremism in Southeast Asia," Deakin University, 2018, unpublished report.

5 Scholars usually refer to paradigms as the philosophical assumptions that guide our way of conducting research. The four main paradigms are usually referred to as: postpositivist, constructivist, transformative, and pragmatic. Postpositivism is based on the rationalistic and empiricist idea that the social world can be studied in the same way as the natural world, and that causality and other mechanisms can be observed with measurement and experimentation. Constructivism proposes that reality is socially constructed, and research is a product of the values of researchers. The tranformative paradigm positions researchers side by side with less powerful and marginalized groups in a joint effort to bring about social transformation. The pragmatic paradigm eludes for the most part metaphysical discussions about truth and reality and looks at the intersubjective relations that compose the social world with a mixed methods approach that includes aspects of postpositivist, constructivist, and transformative approaches. For more discussion about the paradigms of research, see: Donna M. Mertens, Research and evaluation in education and psychology: Integrating diversity with quantitative, qualitative, and mixed methods (US: SAGE Publications, 2014).

6 Matteo Vergani, Muhammad Iqbal, Ekin Ilbahar, and Greg Barton, "The three Ps of radicalization: Push, pull and personal. A systematic scoping review of the scientific evidence about radicalization into violent extremism," Studies in Conflict \& Terrorism 43, no. 10 (2020): 854-854. 
in schools. In the primary P/CVE space, it might include research informing or evaluating strategic communication campaigns.

\section{CONDUCTING P/CVE RESEARCH IN AND WITH LOCALIZED COMMUNITIES}

From many points of view, community actors are in a position of advantage to research violent extremism at the local level. As previous literature reviews have found, ${ }^{7}$ most radicalization and terrorism research use either secondary sources (like propaganda materials) or non-extremist samples (like university students). Accessing individuals and groups that are more at risk of radicalization is crucial but difficult, as communities at risk are usually not open to being researched by people they do not know or trust. Community actors are often able to provide this access because-and as long as-as members of the community themselves, community members trust them.

\section{Understanding trust}

Trust is the universal currency in all exchanges between stakeholders in the P/CVE space, but it is also volatile. In contexts where civil society loses space or is less free to democratically oppose the government, the credibility of community actors can be corrupted by working in the P/CVE field in collaboration with governments, especially in the eyes of those who have little trust in such institutions. This is a common situation in Southeast Asian countries experiencing an ongoing separatist struggle and where the central government does not trust minority communities who share an ethno-religious identity and grievances with the rebels.

For example, in Thailand and the Philippines, both experiencing long-standing separatist struggles in which the separatist minorities are identified along ethno-religious lines, there is a trust deficit between Muslim communities and the central government. In these contexts, P/CVE research and practice is often carried out by community actors (such civil society organizations, leaders, and activists), who are in the difficult position of having to build trust with both the central government and the community members. Trust from the government is necessary to access funding and relationships with government agencies, including law enforcement, correction systems, and local government authorities, and to make sure that the research is put to concrete use by government. Likewise, trust from the communities is necessary to access individuals and groups who would not otherwise participate in any government-funded P/CVE research or intervention program. In an other chapter of this volume, Mikhael and Norman provide a nuanced discussion of how to successfully build trust relationships with local partners for conducting P/ CVE research in conflict zones and divided societies. ${ }^{8}$

7 Vergani, Iqbal, Ilbahar, and Barton, "The three Ps of radicalization".

8 Drew Mikhael and Julie Norman, Getting Local Engagement Right: Key Considerations for Local-level P/CVE Research (Washington, D.C.: RESOLVE Network, 2020) https://doi.org/10.37805/rve2020.5. 


\section{Understanding risk}

Community actors incur significant risks in collaborating with governments and security agencies on $\mathrm{P} /$ CVE research. As Howell suggests, community actors who want to maintain trust from their communities need to remain independent from the aims of the security apparatus and continue addressing issues of social justice, redistribution, and ethnic oppression without being oppressed by the government. ${ }^{9}$ It is important to remember that community actors can be targeted by extremists and hate campaigns, both physically and in social media. Being seen to be working in P/CVE is often dangerous in local contexts where extremist ideologies are normalized and where governments are corrupted or governance is weak. Engagement of community actors in P/CVE puts them at risk of being perceived as aligning with the state's security agenda. In these contexts, trust needs to be balanced with independence.

This risk poses inescapable ethical challenges to P/CVE research, including the risk posed to the security of the researcher and community members in contexts of active conflict. It also creates the potential for bias that can distort research results. If the relationship between community actors and the government is too close, community actors engaged in research will be perceived as tamed, instruments to the government's political agenda, losing the trust of the community members. Similarly, if a community actor is too involved in political competition with other community actors, they will likely lose the trust of part of the community.

Lack of trust from parts of the community translates into research biases such as sample bias, which can affect the quality and reliability of research findings. For example, a community actor that is not trusted by individuals and groups within the community will not be able to access the whole community and will likely overlook important information relevant to P/CVE research questions. This is an important reason why it is in the best interest of governments and other funders of P/CVE research to choose as partners community actors that are truly independent and pursue the empowerment of their communities without political motives.

\section{Understanding researcher independence}

One of the best ways for community actors to achieve independence is through the diversification of funding sources. In their chapter, Malet and Korbitz examine the relationships between P/CVE funders and researchers and the potential challenges arising from different expectations and needs. ${ }^{10} \mathrm{P} / \mathrm{CVE}$ research in Southeast Asia is funded not only by national governments but often by foreign governments, universities, and international NGOs.

9 Jude Howell, "The global war on terror, development and civil society," Journal of International Development: The Journal of the Development Studies Association 18, no. 1 (2006): 121-135.

10 David Malet and Mark Korbitz, Resilience is for Research Designs Too: Funders, Researchers, \& Navigating Study Constraints (Washington, D.C.: RESOLVE Network, 2019) https://doi.org/10.37805/rve2019.7. 
A study conducted in 2019 explored the funding sources of 74 community actors (including civil society organizations, universities, think-tanks, and activists) working on P/CVE in Indonesia, Malaysia, the Philippines, and Thailand. ${ }^{11}$ The study found that all community actors received some funding for P/CVE research and practice from local and foreign governments, and their funding models were heavily reliant on grants. More recently, civil society organizations are starting to work on different funding models, such as social enterprises, to self-fund at least part of their activities. For example, the creation of social enterprises is one of the key focuses of the SEAN-CSO network, which has provided seed funding to local community actors to create small businesses to finance their local P/CVE work.

In Southeast Asia, government trust in community actors tends to crystallize over time into a handful of established and proven partnerships working on P/CVE, mainly consolidated through informal relationships. In Malaysia, Thailand, and the Philippines, these relationships are maintained especially with community actors that are seen as not critical toward the government, which poses a real threat to the independence of research and practice in the P/CVE space.

In a study conducted in 2019, Kruber et al. interviewed 20 members of civil society organizations working on P/CVE in Indonesia, Malaysia, the Philippines, and Thailand to investigate their relationships with local governments. ${ }^{12}$ Most community actors expressed concern about the ephemeral nature of their relationships with their governments, perceived as being dependent on personal relationships, which can be impacted by changes of personnel within government departments and agencies, including through electoral cycles. As indicated by many interviewees, a potential solution to this problem would be the development of formal mechanisms to involve local research actors in P/CVE research, such as within National Action Plans. ${ }^{13}$ These mechanisms should also clearly regulate processes of data sharing between community actors and government agencies within national settings. In this volume, Atamuradova and Nanni provide a list of recommendations for use by researchers and research commissioners in the P/CVE field, which can assist community actors in securing funding for their activities. ${ }^{14}$

\section{Researcher resources and capacity}

While researchers associated with universities and other institutions often have both the resources and the skills to undertake high quality research, community actors often have unique access to communities at risk but sometimes lack the capacities and resources to conduct rigorous, reliable, and well-designed research. The majority of civil society organizations working on P/CVE in Southeast Asia are under-resourced and under-staffed, largely relying on volunteers. In some cases, they are disconnected from the

11 Matteo Vergani, Dewirini Anggraeni, Dan Goodhardt, and Greg Barton, "Capacity-Gap Analysis 2018-2019. Assessment of Civil Society Organisations Working against Violent Extremism in South East Asia," Deakin University, 2019, unpublished report.

12 Samantha Kruber, Matteo Vergani, Greg Barton, Dan Goodhardt, and Titien Yuliatiningtyas, "Capacity-Gap Analysis 2019-2020. Assessment of Government-Civil Society Relationships in CVE: The Perspective of Civil Society Organisations in South East Asia," Deakin University, 2020, unpublished report.

13 Kruber et al., "Capacity-Gap Analysis 2019-2020."

14 Farangiz Atamuradova and Carlotta Nanni, Commissioning Research on Violent Extremism: Lessons Learned from the STRIVE Global Program (Washington, D.C.: RESOLVE Network, 2020) https://doi.org/10.37805/rve2020.6. 
national and international research community and are not well versed in the broad toolkit of methods available to P/CVE researchers. For example, Barton et al. found that evaluation methods among civil society organizations working on P/CVE in Southeast Asia are often unsystematic, with very limited use of control groups or pre- and post-intervention measurements. ${ }^{15}$ Observations, interviews, unstructured conversations, and post-intervention self-reported Likert scales are the norm for evaluating P/CVE programs.

In addition, there is an over-reliance on qualitative methods, textual analyses, and ethnography to investigate radicalization factors by community actors in the South East Asian context, and studies using other methodologies (for example experimental designs) are virtually absent. This lack of methodological breadth is detrimental to the quality and reliability of P/CVE research in the region. Providing basic research training to community members and enhancing collaboration with researchers from local and international institutions could address some of these problems, although the issue of resources and funding remains a key problem in advancing the quality of P/CVE research and evaluations in Southeast Asia.

\section{P/CVE RESEARCH IN AND WITH BROADLY DEFINED COMMUNITIES: CHALLENGES AND OPPORTUNITIES}

$P / C V E$ research in-and with-communities, when intended in a broader sense-for example, tapping into a broad religious identity like the Muslim community-poses a different set of challenges and opportunities.

\section{Variation in causes and risks of radicalization}

Systematic, cumulative, and comparative research is needed to inform P/CVE practice across different contexts within a particular region (like Southeast Asia) or even within a large and diverse country (like Indonesia, for example). In different local contexts, different sets of risk factors and root causes of radicalization might be relevant. For example, research has shown that in post-conflict zones like Iraq, improving service provision reduces insurgent violence, particularly when the provision is made through smaller, community-based projects. ${ }^{16}$ In more stable contexts, the association between development indicators and violence has found to be absent in meta-analytic reviews. ${ }^{17}$

15 Greg Barton, Matteo Vergani, Dan Goodhardt, and Husnul Atiyah, "Gap Analysis and Capacity Assessment of Society Organisations Working against Violent Extremism in Southeast Asia," Deakin University, 2018, unpublished report.

16 Eli Berman, Jacob N. Shapiro, and Joseph H. Felter, "Can hearts and minds be bought? The economics of counterinsurgency in Iraq," Journal of Political Economy 119, no. 4 (2011): 766-819.

17 Aurélie Campana, and Luc Lapointe, "The structural 'root' causes of non-suicide terrorism: A systematic scoping review," Terrorism and Political Violence 24, no. 1 (2012): 79-104. 
Anecdotal evidence suggests that this diversity of contexts and root causes of radicalization exists also within Southeast Asia. Vergani et al. found that, according to 74 community actors working on P/CVE research and practice in Indonesia, Malaysia, the Philippines, and Thailand, political grievances, Islamophobia, and exclusion of Muslim minorities from the political process are seen as one of the main risk factors of radicalization in the Philippines and Thailand, but not in Malaysia or Indonesia. ${ }^{18}$ Rather, returnees from Syria and Iraq linked to the Islamic State are seen as a major issue in these countries. Moreover, Indonesians and Malaysians identify political and religious polarization and hate from Muslim groups toward non-Muslim minorities and LGBTIQ+ groups as another major issue. Other important concerns identified by respondents include the involvement of women and children in terrorist groups and the regional consequences of instability and armed groups' safe havens in the Philippines.

The root causes and risk factors of radicalization across different geographical areas in Southeast Asia are vastly different. However, no systematic comparative research has investigated the different relevance of these factors across the various Southeast Asian local contexts to inform P/CVE practice. Similarly, in the evaluation space, there is no comparative and cumulative knowledge base to understand what $P / C V E$ interventions work or don't work, where, and why. In Southeast Asia, evaluations are conducted mostly by community actors, using different and inconsistent measurement tools and research designs.

\section{Standardization of terms and methods}

An initial barrier to conducting this type of research is the lack of common definitions of violent extremism among Southeast Asian P/CVE stakeholders, including governments and community actors. Research shows that among Southeast Asian community actors terms such as CVE, PVE, and social cohesion are delegitimized by some because they are intrinsically ambiguous and do not allow stakeholders to distinguish clearly between legitimate forms of non-violent radical or fundamentalist religious thought, which are part of the democratic political discourse in Muslim-majority countries, and violent extremism. ${ }^{19}$ For this reason, in Malaysia and Indonesia, the distinction between radicalism and violent extremism is a particularly important aspect of the P/CVE scholarly debate. ${ }^{20}$ In Thailand and the Philippines, where there are separatist insurgencies and Muslims are a religious minority, the distinction between terrorism and freedom fighters, rebels, and insurgents is a key part of the debate. ${ }^{21}$ This lack of shared definitions translates into a lack of comparable research findings across different contexts, which limits the production of cumulative P/CVE knowledge in the region.

18 Vergani et al., "Capacity-Gap Analysis 2018-2019."

19 Vergani et al., "Capacity-Gap Analysis 2018-2019."

20 Alexander R. Arifianto, "Islamic campus preaching organizations in Indonesia: Promoters of moderation or radicalism?" Asian Security 15, no. 3 (2019): 323-342; Choirul Mahfud, Niken Prasetyawati, Wahyuddin Wahyuddin, Zainul Muhibbin, Dyah Satya Yoga Agustin, and Heni Sukmawati, "Religious Radicalism, Global Terrorism and Islamic Challenges in Contemporary Indonesia," Jurnal Sosial Humaniora (JSH) 11, no. 1 (2018): 8-18.

21 Rohan Gunaratna and Muh Taufiqurrohman, "Insurgency and Terrorism in East Asia: Threat and Response," in Non-Traditional Security in East Asia: A Regime Approach, eds. Ramon Pacheco Pardo and Jeffrey Reeves (2016) 23-48. https://doi.org/10.1142/p1008. 
A second barrier to producing cumulative and comparative knowledge in P/CVE research is the lack of consistent methodologies used throughout different research and evaluation studies across local contexts. The diversity of research skills and resources among different community actors produces fragmented knowledge that is difficult for policy makers to interpret, use, or verify. Without consistent methods and cumulative knowledge, it is impossible to have a solid foundation from which to prioritize certain $\mathrm{P} / \mathrm{CVE}$ areas and interventions across large and diverse communities.

A potential solution to these problems would be the creation of a unified research and evaluation framework, developed in consultation with community actors, within a country or potentially across multiple countries that share similar broad communities, sets of stakeholders, grievances, and risk factors. National Action Plans could set some basic foundations for common definitions, measurements, research, and evaluation frameworks. Specific and detailed frameworks should be a priority for networks of government agencies, researchers, practitioners, and community actors to develop. These networks should prioritize sharing research methods and toolkits to spark collaborative and comparative P/CVE research and evaluation across local community contexts.

In support of this recommendation, Vergani et al. found that the need to develop strategic P/CVE frameworks (such as National Action Plans) and the need for more rigorous evaluation of P/CVE programs are at the top of the list of priorities identified by community actors working on P/CVE in Southeast Asia. ${ }^{22}$ Still, some government agencies might be opposed to collaborating with community actors on P/CVE. ${ }^{23}$

\section{Networking and coordination}

To this end, it is important to highlight the presence of numerous networking initiatives and platforms for P/CVE community actors across Southeast Asia. A stable regional initiative funded by the Australian Government is the Southeast Asian Network of Civil Society Organizations (SEAN-CSO) working on addressing violent extremism, which has existed since 2016 and organizes online and face-to-face events and trainings for community and government stakeholders in the region.

Networking between community and government actors often takes place through multilateral initiatives, such as the Global Counter Terrorism Forum (GCTF) sub-committee on CVE led by Australia and Indonesia. Many international donors and P/CVE actors have launched networking initiatives of civil society actors in Southeast Asia. To name just a few, the Global Center on Cooperative Security (funded by the government of the Netherlands) has launched an initiative to strengthen the networks of women-led P/CVE organizations in Southeast Asia. The Philippine Center for Islam and Democracy and the ASEAN

22 Vergani et al., "Capacity-Gap Analysis 2018-2019."

23 I. Gusti Bagus Dharma Agastia, Anak Agung Banyu Perwita, and D. B. Subedi, "Countering violent extremism through state-society partnerships: a case study of de-radicalisation programmes in Indonesia," Journal of Policing, Intelligence and Counter Terrorism 15, no. 1 (2020): 23-43, https://doi.org/10.1080/18335330.2020.1722317; Cameron Sumpter, "Countering violent extremism in Indonesia: priorities, practice and the role of civil society," Journal for Deradicalization 11 (2017): 112-147. 
Society of the Philippines convened a large network of community actors working on P/CVE in Southeast Asia in 2017, funded by numerous governmental and inter-governmental actors.

Since the COVID-19 pandemic and the consequent lockdowns, countless online events are organized every month in Southeast Asia, with the aim of bringing together and training community actors working on P/CVE. While the increase in online networking and training efforts to increase skills, collaboration, and coordination among the variety of actors engaged in the P/CVE space is a positive development, personal communications with local P/CVE actors suggest that this over-proliferation of online events can cause fatigue, duplication, and exhaustion among local community stakeholders, who struggle to locate the events and trainings that are important to them. Online training and networking proliferation is exacerbated by the competing political agendas of funding bodies-e.g. multilateral bodies and foreign governments - and by competition between P/CVE agencies. A curated repository of on- and offline networking and training events in the P/CVE space would be beneficial for scholars and practitioners working in the South East Asian region.

\section{UNDERSTANDING ETHICS: CONSIDERATIONS AROUND MAJORITY AND MINORITY POPULATIONS}

Finally, and importantly, significant ethical implications relate to P/CVE research and practice among both majority and minority communities, broadly defined, in Southeast Asia. On the one hand, the implications for minority communities have been discussed and studied extensively in the literature of critical terrorism studies, particularly in relation to "community-driven" P/CVE approaches in Western countries. ${ }^{24}$ In Southeast Asia, this applies to contexts such as Thailand and the Philippines, where P/CVE research and practice targets the broad Muslim community, incurring the risk of profiling individuals, creating suspect citizens, and silencing dissent and free speech.

On the other hand, the ethical and political implications of P/CVE research and practice among majority communities is rarely discussed. The Southeast Asian context is an optimal case to examine this issue, which applies in similar terms to all countries where P/CVE addresses forms of extremism that are present within majority communities, such as far-right and racially and ethnically motivated violent extremism (REMVE) in Western countries. For example, Berger ${ }^{25}$ discussed the ethical implications of discussing in the public domain research findings showing how some white nationalist extremists have explicitly supported U.S. President Donald Trump, as well as the practical and ethical challenges of conducting P/

24 Nicole Nguyen, Suspect communities: Anti-Muslim racism and the domestic war on terror (US: University of Minnesota Press, 2019); Aislinn O'Donnell, "Securitisation, counterterrorism and the silencing of dissent: The educational implications of prevent," British Journal of Educational Studies 64, no. 1 (2016): 53-76.

25 J.M. Berger, Researching Violent Extremism: The State of Play (Washington, D.C.: RESOLVE Network, 2019), https://doi.org/10.37805/ rve2019.3. 
CVE work in a political context where some policy makers turn a blind eye to extremism among their political supporters.

For the Southeast Asian context, tackling jihadist extremism in Muslim-majority democracies such as Indonesia and Malaysia poses key ethical challenges. The first challenge is related to the use of tax-payers' money to counter ideas that play a major role in a country's democratic process. As in Western countries, in Southeast Asian politics some political leaders incite hatred against non-Muslims and use populist rhetoric and toxic ultra-nationalist narratives based on ethno-religious identities to gather consensus. Sometimes this toxic populism surfaces into mainstream politics. In Malaysia, the government approach has been to dominate the discourse on Islam and attain Malay Muslim support with the creation of a Muslim bureaucracy and the implementation of aspects of religiously based laws. ${ }^{26}$

In these contexts, researching and countering extremist ideologies is politically sensitive, because it has the potential to be instrumentalized by political elites and thus affect political and democratic processes. Tackling the spread of out-group hatred is an important component of primary P/CVE work. However, when hateful and extremist ideas are directly associated with mainstream political movements, despite the presence of ideological contiguity with extremist movements, public and foreign funding invested into researching and countering these ideas can be seen as undue interference. ${ }^{27}$

Over-researching a particular topic could also create imbalances in the public opinion, drawing attention to certain topics over others. ${ }^{28} \mathrm{P} / \mathrm{CVE}$ research can set the agenda of the public, the media, and politicians disproportionately on a certain security issue (for example, hatred spread by a certain political movement). This, by consequence, can demonize a certain political ideology and diminish attention on other areas of public interest (such as education, healthcare, etc.). For example, in the South East Asian context, the politicization of the Patani conflict in Thailand has been associated with a securitized political agendas and the erosion of civil liberties. ${ }^{29}$ For this reason, P/CVE research in the Thai context is very sensitive, with the national Thai government framing P/CVE research on Patani violence as religiously inspired terrorism, and local communities largely contesting this definition and framing the conflict in terms of ethno-nationalist struggle. ${ }^{30}$

Agenda-setting can be exploited by political leaders whose objectives align with P/CVE research and practice for electoral purposes. As Atamuradova and Nanni discuss, donor-driven priorities can significantly distort P/CVE research agendas by focusing research efforts on only one type of violent extrem-

26 Joseph Chinyong Liow, "Political Islam in Malaysia: problematising discourse and practice in the UMNO-PAS 'Islamisation race,"” Commonwealth \& Comparative Politics 42, no. 2 (2004): 184-205.

27 For more, see: Berger, Researching Violent Extremism.

28 See Atamuradova and Nanni, Commissioning Research on Violent Extremism.

29 Croissant, Aurel. "Muslim insurgency, political violence, and democracy in Thailand." Terrorism and Political Violence 19, no. 1 (2007): $1-18$.

30 Bayu Mitra A. Kusuma, "Patani United Liberation Organization: From Jihad to Local Politics Movement." The Indonesian Journal of Public Administration 2, no. 1 (2016). 
ism. ${ }^{31}$ Communities can set P/CVE research agendas to advance their political and economic interests. Funders, communities and political stakeholders can influence and distort how research findings are analyzed and interpreted, sometimes to biased end. Backlash from other political actors can result, further polarizing political attitudes in the country. As a risk mitigation strategy, academics and practitioners in the P/CVE field suggest involving a diversity of stakeholders-including communities, researchers, and law enforcement and government representatives with different viewpoints and agendas - in review boards, advisory boards, and research teams, to make sure all points of views are represented in the research assumptions, questions and methods. ${ }^{32}$

\section{CONCLUSION}

This chapter discussed key aspects to consider when undertaking community-centered P/CVE research in South East Asia. Although the Southeast Asian context is used to discuss the opportunities and challenges of different approaches to community-centered research, the key findings are likely relevant to other contexts too. First, when research is done in-and with-local communities, community actors are in a position of advantage to access samples that would otherwise be overlooked by researchers who are not from the community. However, ethical challenges and potential distortions (such as sample biases) need to be taken carefully into consideration, particularly in contexts like Thailand and the Philippines, where the priorities of $\mathrm{P} / \mathrm{CVE}$ government donors might reflect a political agenda that is perceived as biased by local communities.

Other factors, such as crystallized and tamed relationships between governments and certain community actors, political competition within and between communities, and the lack of research resources and capacities, need to be assessed when conducting P/CVE research with community actors in local contexts. Previous research in the South East Asian context found that the vast majority of funding for P/ CVE research in the region tends to involve a small group of community organizations that act as de-facto gatekeepers of research in this field. ${ }^{33}$ This concentration of funding and resources increases the risks of biased $\mathrm{P} / \mathrm{CVE}$ research in the region.

Second, when research is done in-and with-broader communities, the main challenge is to produce systematic, cumulative, and comparative research findings that hold true across local contexts. To achieve this aim, it can be helpful to establish common definitions, measurement tools, and methodologies in consultation with all stakeholders, including community actors. Practical solutions can include the establishment of research and evaluation frameworks in National Action Plans. However, it is also important to consider that community actors are often invited to networking tables that are set primarily to address the needs of donors, therefore fatiguing community stakeholders by duplicating their efforts

31 Atamuradova and Nanni, Commissioning Research on Violent Extremism.

32 John Horgan and Kurt Braddock, "Rehabilitating the terrorists?: Challenges in assessing the effectiveness of de-radicalization programs," Terrorism and Political Violence 22, no. 2 (2010): 267-291; Atamuradova and Nanni, Commissioning Research on Violent Extremism. 
and weakening broader P/CVE objectives. In Southeast Asia, Indonesia is leading the way in creating a National Action Plan that includes a strong focus on lifting the quality of P/CVE research in the country, by providing skills and training to community and research actors to produce reliable, valid, and cumulative P/CVE knowledge. ${ }^{34}$

Finally, it is important to consider specific ethical challenges related to working with minority communities - such as the creation of suspicious, ostracized, and alienated communities-but also with majority communities - and the potential for research findings and topics of focus interfering in or being instrumentalized to impact a country's political and democratic process, which is a key issue for international P/CVE donors working in South East Asia. 


\section{SOURCES}

Agastia, I. Gusti Bagus Dharma, Anak Agung Banyu Perwita, and D. B. Subedi. "Countering violent extremism through state-society partnerships: a case study of de-radicalisation programmes in Indonesia." Journal of Policing, Intelligence and Counter Terrorism 15, no. 43-23 :(2020) 1. https://doi.org/10.1080/ $\underline{18335330.2020 .1722317}$

Anderson, Benedict. Imagined communities: Reflections on the origin and spread of nationalism. London: Verso books, 2006.

Arifianto, Alexander R. “Islamic campus preaching organizations in Indonesia: Promoters of moderation or radicalism?” Asian Security 15, no. 3 (2019): 323-342.

Association of Southeast Asian Nations (ASEAN). "Asean Plan Of Action To Prevent And Counter The Rise Of Radicalisation And Violent Extremism (2018 2025)." 2018. https://asean.org/storage/2012/05/Adopted-ASEAN-PoA-to-Prevent-and-Counter-PCVE.pdf

Atamuradova, Farangiz, and Carlotta Nanni. Commissioning Research on Violent Extremism: Lessons Learned from the STRIVE Global Program. Washington, D.C.: RESOLVE Network, 2020. https://doi.org/10.37805/rve2020.6

Barton, Greg, Vergani, Matteo, Goodhardt, Dan, Atiyah, Husnul. "Gap Analysis and Capacity Assessment of Society Organisations Working against Violent Extremism in Southeast Asia." Deakin University, 2018, unpublished report.

Barton, Greg. Gus Dur: The Authorized Biography of Abdurrahman Wahid. UK: Equinox Publishing, 2002.

Berger, J.M. Researching Violent Extremism: The State of Play. Washington, D.C.: RESOLVE Network, 2019. https://doi.org/10.37805/rve2019.3.

Berman, Eli, Jacob N. Shapiro, and Joseph H. Felter. "Can hearts and minds be bought? The economics of counterinsurgency in Iraq." Journal of Political Economy 119, no. 4 (2011): 766-819.

Campana, Aurélie, and Luc Lapointe. "The structural "root" causes of non-suicide terrorism: A systematic scoping review." Terrorism and Political Violence 24, no. 1 (2012): 79-104.

Chinyong Liow, Joseph. "Political Islam in Malaysia: problematising discourse and practice in the UMNO-PAS 'Islamisation race.'” Commonwealth \& Comparative Politics 42, no. 2 (2004): 184-205.

Croissant, Aurel. “Muslim insurgency, political violence, and democracy in Thailand.” Terrorism and Political Violence 19, no. 1 (2007): 1-18.

Gunaratna, Rohan, and Muh Taufiqurrohman. "Insurgency and Terrorism in East Asia: Threat and Response." In Non-Traditional Security in East Asia: A Regime Approach, edited by Ramon Pacheco Pardo and Jeffrey Reeves, 23-48. 2016. https://doi.org/10.1142/p1008.

Horgan, John, and Kurt Braddock. "Rehabilitating the terrorists?: Challenges in assessing the effectiveness of de-radicalization programs." Terrorism and political violence 22, no. 2 (2010): 267-291.

Howell, Jude. "The global war on terror, development and civil society." Journal of International Development: The Journal of the Development Studies Association 18, no. 1 (2006): 121-135.

Kruber, Samantha, Vergani, Matteo, Barton, Greg, Goodhardt, Dan, Yuliatiningtyas, Titien. “Capacity-Gap Analysis 2019-2020. Assessment of Government-Civil Society Relationships in CVE: The Perspective of Civil Society Organisations in South East Asia." Deakin University, 2020, unpublished report.

Kusuma, Bayu Mitra A. "Patani United Liberation Organization: From Jihad to Local Politics Movement." The Indonesian Journal of Public Administration 2, no. 1 (2016).

Mahfud, Choirul, Niken Prasetyawati, Wahyuddin Wahyuddin, Zainul Muhibbin, Dyah Satya Yoga Agustin, and Heni Sukmawati. "Religious Radicalism, Global Terrorism and Islamic Challenges in Contemporary Indonesia." Jurnal Sosial Humaniora (JSH) 11, no. 1 (2018): 8-18.

Malet, David, and Mark Korbitz. Resilience is for Research Designs Too: Funders, Researchers, \& Navigating Study Constraints. Washington, D.C.: RESOLVE Network, 2019. https://doi.org/10.37805/rve2019.7.

Mertens, Donna M. Research and evaluation in education and psychology: Integrating diversity with quantitative, qualitative, and mixed methods. US: SAGE publications, 2014.

Mikhael, Drew, and Julie Norman. Getting Local Engagement Right: Key Considerations for Local-level P/CVE Research. Washington, D.C.: RESOLVE Network, 2020. https://doi.org/10.37805/rve2020.5.

Nguyen, Nicole. Suspect communities: Anti-Muslim racism and the domestic war on terror. US: University of Minnesota Press, 2019.

O'Donnell, Aislinn. "Securitisation, counterterrorism and the silencing of dissent: The educational implications of prevent." British Journal of Educational Studies 64, no. 1 (2016): 53-76.

Sumpter, Cameron. "Countering violent extremism in Indonesia: priorities, practice and the role of civil society." Journal for Deradicalization 11 (2017): $112-147$. 
United Nations Development Program (UNDP) Indonesia. "UNDP Indonesia join forces with BNPT to establish action plan on violent extremism prevention." January 23, 2020. https://www.id.undp.org/content/indonesia/en/home/presscenter/pressreleases/2020/UNDP-Indonesia-Join-Forces-with-BNPT. $\underline{\mathrm{html}}$.

Vergani, Matteo, Dewirini Anggraeni, Dan Goodhardt, and Greg Barton. "Capacity-Gap Analysis 2018-2019. Assessment of Civil Society Organisations Working against Violent Extremism in South East Asia." Deakin University, 2019, unpublished report.

Vergani, Matteo, Muhammad Iqbal, Ekin Ilbahar, and Greg Barton. "The three Ps of radicalization: Push, pull and personal. A systematic scoping review of the scientific evidence about radicalization into violent extremism." Studies in Conflict \& Terrorism 43, no. 10 (2020): 854-854. 